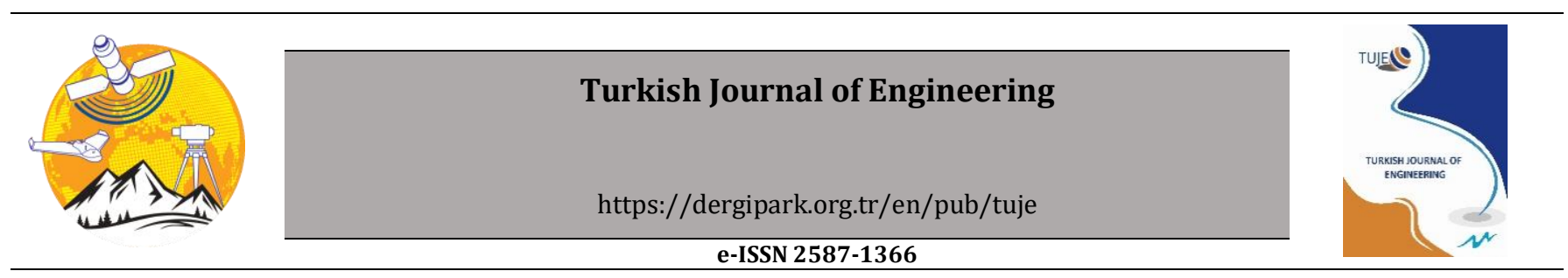

\title{
The investigation of hardness and density properties of GFRP composite pipes under seawater conditions
}

\author{
Alper Gunoz ${ }^{* 1}$, Yusuf Kepir1 ${ }^{1}$, Memduh Kara1® \\ ${ }_{1}^{1}$ Mersin University, Faculty of Engineering, Mechanical Engineering Department, Mersin, Turkey
}

\author{
Keywords \\ Composite pipes \\ Seawater effect \\ Hardness \\ Density
}

\begin{abstract}
Glass fiber reinforced polymer (GFRP) composite pipes are mostly used in transmission lines of submarine oil, natural gas, and chemical fluids. The alterations in mechanical characteristics of composite pipes used in submarine applications are of great importance to the lifespan of the material. Some important mechanical properties of composite materials are density and hardness value. In this study, the changes in the density and hardness values of GFRP composite pipes which were unexposed to seawater and exposed to seawater for 1, 2 and 3 months were investigated. As a result of the present study, it was deduced that the characteristics of the sample changed with the effect of seawater.
\end{abstract}

\section{INTRODUCTION}

Glass Fiber Reinforced Polymers (GFRP) are composite materials produced by incorporating glass fiber into resin as a reinforcement material. Numerous studies have been conducted on the mechanical properties of glass fiber pipes due to the rapid increase in their usage. GFRP composites are suitable for use in naval constructions. On account of their superior wear resistance and lightness properties, GFRP composite pipes are mostly used in transmission lines of submarine oil, natural gas, and chemical fluids (Gellert and Turley, 1999; Kootsookos et al., 2001; Kara, 2012; Kara et al., 2014; Uyaner et al., 2014). It is also widely used in civil defense and aerospace sectors due to its many advantages, such as long lifespan and low cost (Schutte, 1994).

Fiber-reinforced composite pipes used in these fields are exposed to various fluids that may have aggressive effects on the pipes' material composition. The mechanical properties of composite materials change irreversibly when exposed to environmental terms such as humidity and temperature for a long time. This change in the characteristics of composite materials is called ageing. Changes in mechanical characteristics of materials under environmental conditions such as humidity, temperature, pure water, saltwater, and ultraviolet radiation should be well known for determining the strength and service life of composite materials at the places of usage (Doğan, 2014). Many polymer materials absorbed water when they left in water for a long time. This absorbed water disrupts the interfacial bonds and changes the characteristics of the polymers. Absorbed water softens the material, so it increases the distance of the polymer chains (Papanicolaou et al., 2006; Mouzakis et al., 2008; Baschek et al., 1998). Stresses procured by absorbed water cause expansion. Consequently, the damage tolerance and structural strength of the material is reduced. Water absorption creates reversible and irreversible interactions in the mechanical characteristics of polymer composites. Degradation of mechanical characteristics by water absorption causes some unwanted formation such as micro-cracks, interfacial damages, plastification, and swelling of the polymer. The plastification causes plastic deformation by reducing the glass transition temperature ( $\mathrm{Tg}$ ) of the material. The water absorbed into the material forms expansion forces and the polymer chains are forced under the influence of these forces (Saha and Bal 2018; Lee et al., 1993). Glass reinforced plastic materials when remained in the water for a long time, the damage caused by water creates a significant change in creep, tension and fatigue characteristics of the materials (Liao et al., 1998). The mechanical characteristics of the matrix and the fiber/matrix interface area are the essential factors in controlling the performance of GFRP in a fluid medium (Schutte, 1994). 
The fibers are also sensitive to water and moisture degradation (Chu et al., 2004).

Researchers reported that water absorption of polymer matrix composite materials takes place in accordance with Fick's law. In order to figure out the behaviors of the composites under the hydrothermal ageing process, it's necessary well to know the relation between mechanical efficiency, dimensional stability, and water uptake rate (Ferreira et al., 2007; Mouzakis, 2008; Pavan et al., 2001; Zhang et al., 2000; Zhou et al., 2019). On the other hand, some researchers consider that the water absorption process to be non-Fickian, on account of causes such as the polymers' viscoelastic nature and ensure cracks (Shen and Springer, 1976; Pritchard and Speake, 1987; Carter and Kibler, 1978).

One of the composite material production methods is filament winding to produce cylindrical parts such as pressure vessels, water tanks, and pipes. Composite pipes with circular cross-section generally used in applications where fluids are transported, have high strength/weight ratio, fatigue resistance, good corrosion, and high hardness properties (Alderson and Evans, 1992). In the production with filament winding, glass fibers are generally preferred as reinforcement material. The furthest widely used matrix material in polymer composite materials is epoxy resin. Epoxy resin is preferred because of its superior properties such as high tensile, impact resistance and abrasion strength, high electrical and chemical resistance.

In literature, many studies examine the seawater effect on the mechanical characteristics of GFRP composite materials (Gellert and Turley, 1999; Visco et al., 2011; Pal et al., 2012; Davies and Rajapakse, 2014). Karakuzu et al. (2014) studied the effect of seawater and distilled water immersion time periods on mechanical properties of GFRP composites. They performed Tension, compression, and shear tests. Results showed that immersion time affects mechanical properties and strength values of glass-epoxy composites significantly. Seawater causes degradation in the mechanical properties of composite materials (Shenoi and Wellicome, 1993). Buehler and Seferis (2000) observed that degradation in mechanical characteristics of glass and carbon fiber reinforced epoxy resin matrix composites due to water absorption. Kawagoe et al. (2001) observed that the molecules of seawater present in stacks at the glass fiber reinforced epoxy interface where reactions of hydrolysis occur, causing interfacial fractures. Aktaş and Uzun (2008) examined the seawater effect on bearing strength of the GFRP composites. They observed a $10 \%$ decrease in bearing strength. Dehkordi et al. (2010) produced glass fiber epoxy and basalt fiber epoxy composites in their studies and exposed the produced composites to seawater corrosion. They determined the waiting time of composite pipes in the water as 10, 20, 30, and 50 days. They found a significant decrease in the strength of composites over 10 days. Wei et al. (2011) maintained glass and basalt fiber reinforced composites in seawater. They observed a dramatic decrease in mechanical properties in the seawater environment for the first 30 days. Summerscales (2013) observed the strength of epoxy and vinyl ester resins as a function of aging time and temperature. Katunin et al.
(2015) studied the effect of deionized and natural seawater ageing on the change of static and dynamic characteristics of GFRP composite laminates such as hardness, Young's modulus and tensile strength. They observed a decrease in structure strength and found lower hardness values than unaged GFRP composite material. Chakraverty et al. (2015) studied glass fiber reinforced composite materials to determine the seawater's effect on Tg value and weight loss of the composites. The effect of seawater ageing on mechanical and thermo-mechanical behavior of the carbon nanofiber reinforced polymer composites was studied by Saha and Bal (2018). The conclusions indicated a general reduction in hardness, strength, and Tg value of aged samples as compared to non-aged samples due to the absorption of seawater.

In this study, the GFRP composite samples aged in seawater for 1, 2 and 3 months and then the hardness and density properties of the aged samples compared with non-aged GFRP samples.

\section{METHOD}

\subsection{Production of GFRP Pipes}

In the filament winding method; the fiber winding process begins by pulling a certain number of fibers into the resin bath. The fibers, which then pass through the rollers and become bundles, become a single bundle with the help of a guide. This guide moves back and forth, while the rotary mandrel rotates around its axis at a certain speed. The ratio of rotational and feed speeds determines the angle of fiber fibers wound on the mandrel. The production process of GFRP composite pipes is shown in Figure 1.

In the present study, it was used the GFRP composite pipes with $\pm 55^{\circ}$ winding angle. The dispersion phase used in the GFRP composite pipes was $17 \mu$ m diameters Vetrotex 1200 tex E-glass, while the matrix phase was Araldite CY 225 epoxy resin. The mechanical characteristics of epoxy matrix and e-glass fiber materials used are given in Table 1 (Kara, 2012). The fiber volume ratio of the composite samples is 0.50 degree.

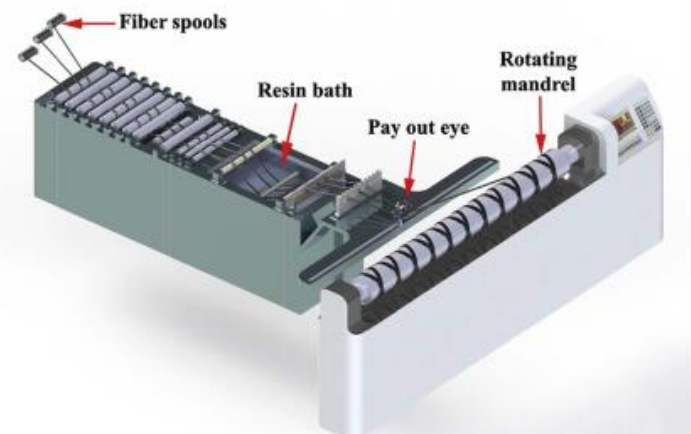

Figure 1. Filament winding process (Kara et al. 2018)

Table 1. Mechanical characteristics of fiber and matrix phases of the composite pipes used (Kara, 2012)

\begin{tabular}{lcccc}
\hline & $\begin{array}{c}\mathrm{E} \\
(\mathrm{GPa})\end{array}$ & $\begin{array}{c}\sigma_{\mathrm{t}} \\
(\mathrm{MPa})\end{array}$ & $\begin{array}{c}\rho \\
\left(\mathrm{g} / \mathrm{cm}^{3}\right)\end{array}$ & $\begin{array}{c}\varepsilon_{\text {rupture }} \\
(\%)\end{array}$ \\
\hline E-glass & 73 & 2400 & 2.6 & $1.5-2$ \\
Epoxy & 3.4 & $50-60$ & 1.2 & $4-5$ \\
\hline
\end{tabular}




\subsection{Seawater Ageing}

In this study, Mediterranean water was used for ageing process because of the fact that Mediterranean water has high salinity that is suitable for the corrosive environment conditions of the composites. The salinity rate of Mediterranean water is 3.8\%. In addition, high amounts of $\mathrm{NaCl}, \mathrm{MgCl}, \mathrm{MgSO}_{4}, \mathrm{CaSO}_{4}, \mathrm{~K}_{2} \mathrm{SO}_{4}, \mathrm{CaCo}_{3}$, $\mathrm{MgBr} 7$ salts are present in the Mediterranean water. The minerals found in the Mediterranean water are shown in Table 2 (Demirci, 2017). The GFRP composite pipes subjected to ageing in seawater are shown in Fig. 2.

When the studies (Saha and Bal 2018; Wei et al., 2011) in the literature were examined, it was observed that different ageing periods were used. In the present study, the GFRP pipes were subjected to seawater ageing for 1,2 and 3 months.

Table 2. Percentage of elements in Mediterranean water (Demirci, 2017)

\begin{tabular}{llll}
\hline Element & Rate & Element & Rate \\
\hline Oxygen & 85.84 & Sulfur & 0.091 \\
Hydrogen & 10.82 & Calcium & 0.04 \\
Chlorine & 1.94 & Potassium & 0.04 \\
Sodium & 1.08 & Bromine & 0.0067 \\
Magnesium & 0.1292 & Carbon & 0.0028 \\
\hline
\end{tabular}

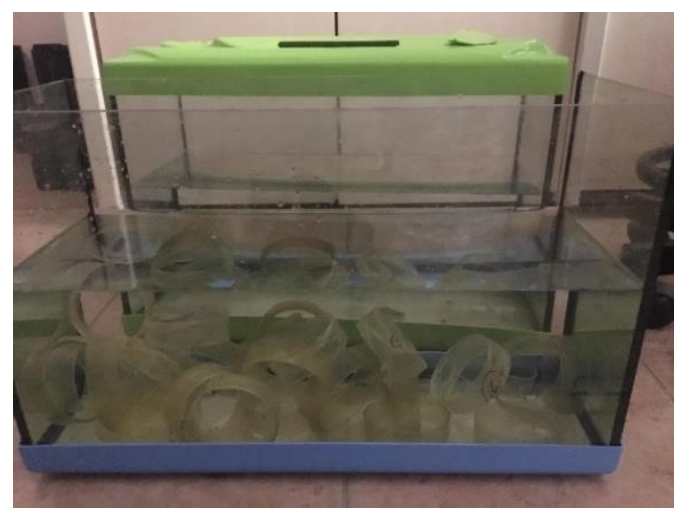

Figure 2. Samples exposed to seawater ageing

\subsection{Hardness Test}

The hardness of samples was measured using a Rockwell hardness testing machine is shown in Fig. 3.

Test specimens (Figure 4) were made in accordance with the ASTM D785. According to the standard L scale of Rockwell hardness tester, the diameter of the indenter was as $6.35 \mathrm{~mm}$ and the maximum load applied was chosen as $60 \mathrm{~kg}$. The Rockwell hardness test was performed at the $25^{\circ} \mathrm{C}$ temperature for all the specimens. All the measurements were taken $10 \mathrm{~s}$ after the indenter made strict contact with the specimen. The hardness was measured from three different places of each specimen and the average hardness values were calculated. Since the outer surfaces of the composite pipes produced have a rougher structure than their inner surfaces, hardness measurements were made from the inner surfaces.
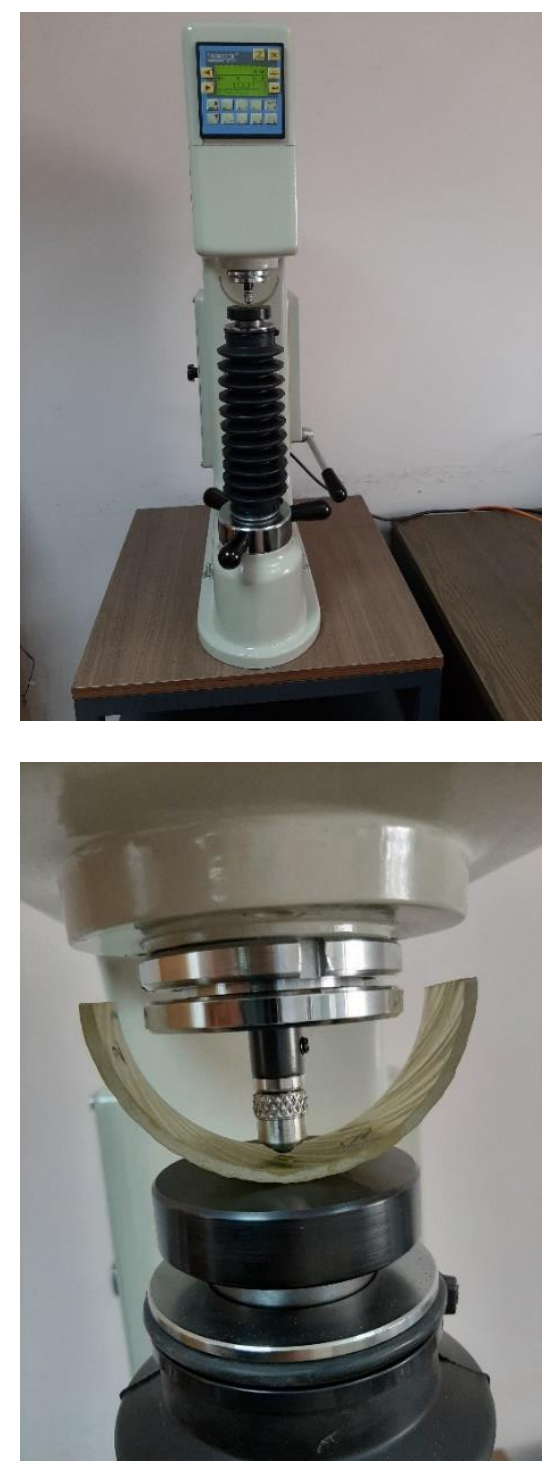

Figure 3. Digital Rockwell hardness tester

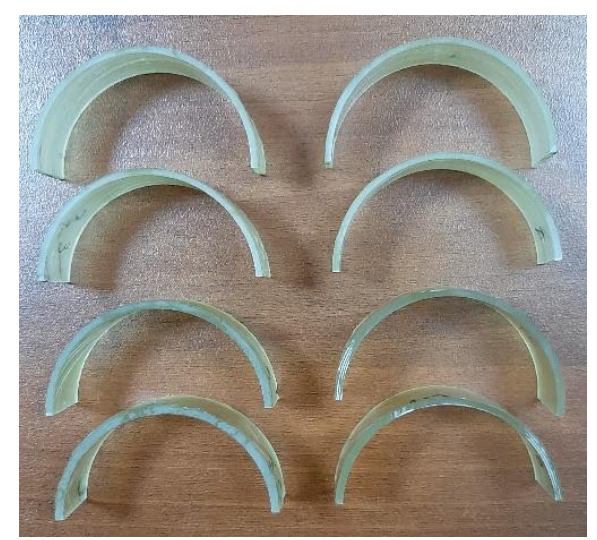

Figure 4. Samples for hardness test

\subsection{Density Measurement Method}

The density value of the specimens was calculated according to the Archimedes principle given in Eq. (1). In this equation, $\rho, \rho_{\text {water, }} W_{\text {air }}$ and $W_{\text {water }}$ are the density $\left(\mathrm{g} / \mathrm{cm}^{3}\right)$ of GFRP sample, the density $\left(\mathrm{g} / \mathrm{cm}^{3}\right)$ of water, the weight $(\mathrm{g})$ of sample in air and the weight $(\mathrm{g})$ of sample in water, respectively. Firstly, the sample was weighed in air as shown in Fig. 5a and then the sample 
was placed in a pot as shown in Fig. $5 \mathrm{~b}$ and weighed in water at $25 \pm 4 \stackrel{\circ}{\circ} \mathrm{C}$.

$$
\rho=\frac{W_{\text {air }}}{W_{\text {air }}-W_{\text {water }}} \rho_{\text {water }}
$$

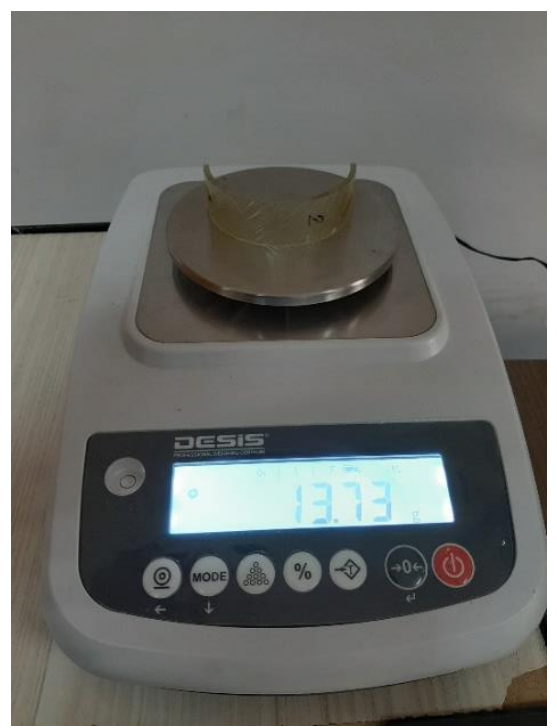

(a)

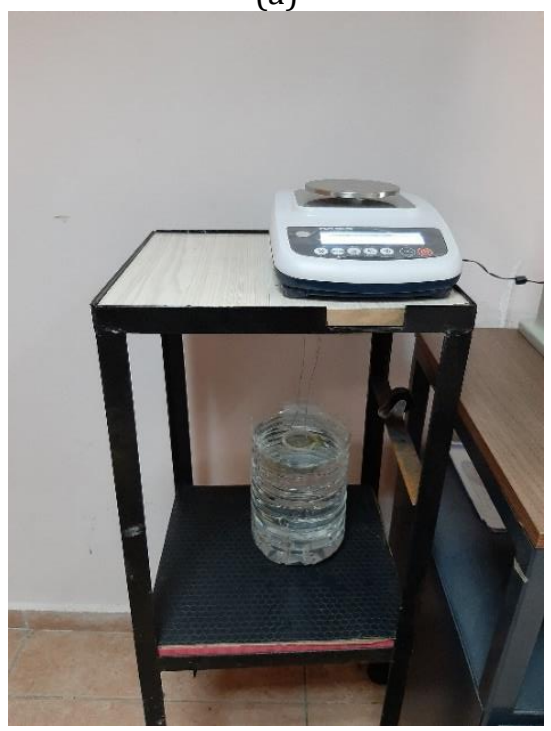

(b)

Figure 5. a) Dry and b) wet weighing of the composite specimen with precision scales

\section{RESULTS AND DISCUSSION}

The exposure time of composite test specimens to seawater was determined according to the literature support. Wei et al. (2011) studied the change of mechanical characteristics of glass and basalt fiber reinforced epoxy composite samples with seawater aging. In their studies, they stated that the first 30 days were very effective in the change of mechanical properties and that after 30 days the change took constant values. They stated that the composite samples absorbed moisture in the seawater environment within 30 days and the water molecules enter the sample and that cause the mass increase.

In this study, it was observed that there was a change in the hardness values depending on the seawater molecules entering the sample. Hardness tests were determined according to the Rockwell method. 1 month of exposure of composites to the marine environment increased hardness value by $1.04 \%$. The average hardness values continued to increase as the ageing time increases. The hardness values of aged and non-aged samples are given in Table 3.

Table 3. Average Rockwell hardness value

\begin{tabular}{cc}
\hline Ageing times (months) & Rockwell hardness (HRL) \\
\hline 0 & 106.1 \\
1 & 107.2 \\
2 & 111.4 \\
3 & 112.1 \\
\hline
\end{tabular}

Because of the corrosive effect of the saline water entering the sample, epoxy resin, one of the structures forming the composite, undergo wear (Wei et al. 2011). The hardness value is expected to increase as the fiber volume ratio of the sample increases due to the abrasion of the epoxy. Because the hardness value of glass fiber is much higher than epoxy. Thus, it was seen that the average hardness of specimens exposed to seawater was higher than not exposed to seawater in this study. In addition, the average hardness values of the specimens increased as the aging times in seawater increased.

Density values of composite samples exposed and unexposed to saline water are given in Figure 6 . When the figure is examined, it is seen that waiting in saltwater increases the density of the composite sample by $6.9 \%$ for one-month period. It is clearly seen in Figure 6 that the density values continue to increase as the ageing time increases. The reason for this is that the saltwater erodes the epoxy, therefore, it can be considered as an increase in the sample's fiber volume ratio. The density of the fiber is much higher than the epoxy. Density increase realized with increasing fiber volume ratio.

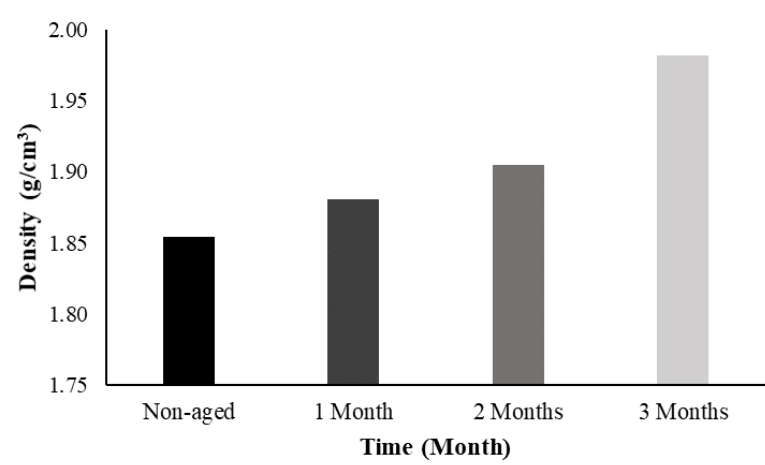

Figure 6. Average density value of composite samples exposed to and unexposed to seawater

\section{CONCLUSION}

In this study, the effect of ageing process in sea water on the hardness and density values of GFRP composite pipes were investigated. As result of study;

- Hardness values of samples exposed to seawater increased due to the abrasion of the epoxy.

- It was observed that the density value of the samples exposed to seawater increased due to the change in fiber volume ratio. 


\section{Author contributions}

Alper GÜNÖZ: Conceptualization; Material supplying; Data curation; Investigation; Methodology; Resources; Visualization; Manuscript writing. Yusuf KEPİR: Conceptualization; Material supplying; Investigation; Methodology; Visualization; Manuscript writing. Memduh KARA: Conceptualization; Material supplying; Supervision; Validation; Review \& editing.

Conflict of Interest: The authors have no conflicts of interest to declare.

\section{REFERENCES}

Aktaş A \& Uzun İ (2008). Sea water effect on pinned-joint glass fibre composite materials. Composite structures, 85(1), 59-63.

Alderson K L \& Evans K E (1992). Low velocity transverse impact of filament-wound pipes: Part 1. Damage due to static and impact loads. Composite structures, 20(1), 37-45.

ASTM D 785 (1993), Rockwell Hardness of Plastics and Electrical Insulating Materials. American Society for Testing and Materials, ASTM International, West Conshohocken, PA, 2006, www.astm.org.

Baschek G, Hartwig G \& Zahradnik F (1998). Effect of water absorption in polymers at low and high temperatures. Polymer, 40, 3433-3441.

Buehler F U \& Seferis J C (2000). Effect of reinforcement and solvent content on moisture absorption in epoxy composite materials. Composites Part A: Applied Science and Manufacturing, 31(7), 741-748.

Carter H G \& Kibler K G (1978). Langmuir-type model for anomalous moisture diffusion in composite resins. Journal of Composite Materials, 12(2), 118-131.

Chakraverty A P, Mohanty U K, Mishra S C \& Satapathy A. (2015). Sea water ageing of GFRP composites and the dissolved salts. In IOP conference series: materials science and engineering (Vol. 75, No. 1, p. 012029). IOP Publishing.

Chu W, Wu L \& Karbhari V M (2004). Durability evaluation of moderate temperature cured Eglass/vinylester systems. Composite Structures, 66(1-4), 367-376.

Davies P \& Rajapakse Y D (2014). Durability of composites in a marine environment (Vol. 208). Springer, Berlin, Germany.

Dehkordi M T, Nosraty H, Shokrieh M M, Minak G \& Ghelli D (2010). Low velocity impact properties of intra-ply hybrid composites based on basalt and nylon woven fabrics. Materials and Design, 31(8), 3835-3844.

Demirci I (2017). Karbon nanotüp ve nano silika takviyeli bazalt/epoksi hibrit nanokompozitlerin korozif ortamda darbe davranışları. Master's Thesis, Selçuk University, Konya, Turkey.

Doğan A (2014). Farklı çevresel koşullara maruz kompozitlerin mekanik davranışları. Master's Thesis, Dokuz Eylül University, Izmir, Turkey.

Ferreira J M, Pires J T B, Costa J D, Errajhi O A \& Richardson M (2007). Fatigue damage and environment interaction of polyester aluminized glass fiber composites. Composite structures, 78(3), 397-401.

Gellert E P \& Turley D M (1999). Seawater immersion ageing of glass-fibre reinforced polymer laminates for marine applications. Composites Part A: Applied Science and Manufacturing, 30(11), 1259-1265.

Kara M (2012). Düşük hızlı darbe sonrası yama ile tamir edilmiş filaman sarım CTP boruların iç basınç altındaki hasar davranışı. Doctoral Thesis, Selçuk University, Konya, Turkey.

Kara M, Uyaner M, Avcı A \& Akdemir A (2014). Effect of non-penetrating impact damages of pre-stressed GRP tubes at low velocities on the burst strength. Composites: Part B, 60, 507-514.

Kara M, Kırıcı M, Tatar A C \& Avcı A (2018). Impact behavior of carbon fiber/epoxy composite tubes reinforced with multi-walled carbon nanotubes at cryogenic environment. Composites Part B: Engineering, 145, 145-154.

Karakuzu R, Kanlioglu H, \& Deniz M E (2014). Environmental Effects on Mechanical Properties of Glass-Epoxy Composites. Materials Testing, 56(5), 355-361.

Katunin A, Gnatowski A \& Kajzer W (2015). Evolution of static and dynamic properties of GFRP laminates during ageing in deionized and seawater. Advanced Composites Letters, 24(3), 096369351502400302.

Kawagoe M, Doi Y, Fuwa N, Yasuda T \& Takata K (2001). Effects of absorbed water on the interfacial fracture between two layers of unsaturated polyester and glass. Journal of materials science, 36(21), 51615167.

Kootsookos A, Mourotz A P \& St John N A (2001). Comparison of the seawater durability of carbon and glass polymer composites. Proceedings of the 13th International Conference on Composite Materials, ID1200, Proceedings of ICCM-13, Beijing.

Lee T H Y C, Freddy \& Loh N L (1993). Characterization of a fibre-reinforced PPS composite by dynamic mechanical analysis: effect of aspect ratio and static stres. Composite science and technology, 49, 217-223.

Liao K, Schultesiz C R, Hunston D L \& Brinson L C (1998). Long-term durability of fiber-reinforced polymermatrix composite materials for infrastructure applications: a review. Journal of advanced materials, 30(4):3-40.

Mouzakis D E, Zoga H and Galiotis C (2008). Accelerated environmental ageing study of polyester/glass fiber reinforced composites (GFRPCs). Composites part B: engineering, 39(3), 467-475.

Pal R, Murthy H N, Sreejith M, Mahesh K V, Krishna M \& Sharma S C (2012). Effect of laminate thickness on moisture diffusion of polymer matrix composites in artificial seawater ageing. Frontiers of Materials Science, 6(3), 225-235.

Papanicolaou G C, Kosmidou T V, Vatalis A S \& Delides C G (2006). Water absorption mechanism and some anomalous effects on the mechanical and viscoelastic behavior of an epoxy system. Journal of Applied Polymer Science, 99(4), 1328-1339.

Pavan R M, Saravanan V, Dinesh A R, Rao Y J, Srihari S \& Revathi A (2001). Hygrothermal effects on painted and unpainted glass/epoxy composites-Part A: 
moisture absorption characteristics. Journal of reinforced plastics and composites, 20(12), 10361047.

Pritchard G \& Speake S D (1987). The use of water absorption kinetic data to predict laminate property changes. Composites, 18(3), 227-232.

Saha S \& Bal S (2018). Long term hydrothermal effect on the mechanical and thermo-mechanical properties of carbon nanofiber doped epoxy composites. Journal of Polymer Engineering, 38(3), 251-261.

Schutte C L (1994). Environmental durability of glassfiber composites. Materials Science and Engineering: R: Reports, 13(7), 265-323.

Shen C H \& Springer G S (1976). Moisture absorption and desorption of composite materials. Journal of composite materials, 10(1), 2-20.

Shenoi R A \& Wellicome J F (1993). Composite Materials in Maritime Structures: Fundamental Aspects (Vol. 1). Cambridge University Press, England.

Summerscales J (2013). Durability of composites in the marine environment. Solid Mechanics and Its Applications, Vol 208, no. 3, pp. 1-13.
Uyaner M, Kara M \& Şahin A. (2014). Fatigue Behavior of Filament Wound E-Glass/Epoxy Composite Tubes Damaged by Low Velocity Impact. Composites: Part B, 61, 358-364.

Wei B, Cao H \& Song S (2011). Degradation of basalt fibre and glass fibre/epoxy resin composites in seawater. Corrosion Science, 53(1), 426-431.

Visco A M, Campo N \& Cianciafara P (2011). Comparison of seawater absorption properties of thermoset resins based composites. Composites Part A: Applied Science and Manufacturing, 42(2), 123-130.

Zhang S, Karbhari V M, Mai L Y \& Mai Y W (2000). Evaluation of property retention in E-glass/vinylester composites after exposure to salt solution and natural weathering. Journal of reinforced plastics and composites, 19(9), 704-731.

Zhou H, Wang G, Chen L, Yu Z, Smith L M \& Chen F (2019). Hydrothermal Aging Properties of Three Typical Bamboo Engineering Composites. Materials, 12(9), 1450. 